Saudi Journal of Business and Management Studies Abbreviated Key Title: Saudi J Bus Manag Stud ISSN 2415-6663 (Print) |ISSN 2415-6671 (Online) Scholars Middle East Publishers, Dubai, United Arab Emirates Journal homepage: https://saudijournals.com/sjbms

Original Research Article

\title{
The Effect of Experiential Marketing Factors on the Competitiveness of Islamic Higher Education in Indonesia
}

\author{
Prim Masrokan Mutohar ${ }^{1 *}$, Nik Haryati ${ }^{2}$ \\ ${ }^{1}$ Posgraduate Program of IAIN Tulungagung, East Java, Indonesia \\ ${ }^{2}$ Student Posgraduate Program of IAIN Tulungagung, East Java, Indonesia
}

DOI: $10.36348 /$ sjbms.2020.v05i06.003

| Received: 28.05.2020 | Accepted: 04.06.2020 | Published: 12.06.2020

*Corresponding author: Prim Masrokan Mutohar

\section{Abstract}

The challenge faced by Islamic higher education in the global era at this time is to improve the quality and competitiveness of higher education so that it is sought after by the education user community. The quality and competitiveness of higher education must be promoted and marketed to the wider community so that it can be known and sought after by the education user community. The purpose of this study was to determine the effect of experiential marketing factors on the competitiveness of Islamic higher education in Indonesia. This study uses a quantitative research design with a survey technique of teaching staff. The survey was conducted on 200 educational staff of Islamic higher educations in East Java, Indonesia. Data were collected using a questionnaire and analyzed using SEM AMOS. Hypothesis test results indicate that there is no effect between factor sense and feel marketing on the competitiveness of Islamic Higher Education in Indonesia and there is a significant effect between think, act, and relate marketing factors on the competitiveness of Islamic higher education in Indonesia. The better in implementing think, act, and related marketing can improve the competitiveness of Islamic Universities. These variable conditions need to be improved in implementing experiential marketing education so that universities are increasingly in demand by stakeholders.

Keywords: Experiential Marketing Factors, College Competitiveness.

Copyright @ 2020: This is an open-access article distributed under the terms of the Creative Commons Attribution license which permits unrestricted use, distribution, and reproduction in any medium for non-commercial use (NonCommercial, or CC-BY-NC) provided the original author and source are credited.

\section{INTRODUCTION}

Improving the quality and competitiveness of higher education has become the focus of attention in increasing the support and interest of the education user community. Increasing competitiveness becomes very important when there are growth and development of the quantity and quality of tertiary institutions which are increasing both at national and international levels. At present there are 2,960 Higher Education Institutions in Indonesia consisting of 204 State Universities and 2,756 Private Universities. International competition related to the quality of graduate competencies, the ability to master international languages, the ability to collaborate, the results of research, the programs implemented, the ability of lecturers, and overall is the quality of higher education [1]. Higher education competition in ASEAN countries is increasingly visible after the ASEAN Economic Community (AEC) [2].
The presence of the AEC provides opportunities for foreign universities to establish universities in the territory of Indonesia. This condition is strengthened by Law No. 12 of 2012 Article 90 on Higher Education explaining that universities in other countries can organize Higher Education in the territory of Indonesia in collaboration with Universities in Indonesia and with the permission of the government. Efforts to improve the competitiveness of tertiary institutions will continue to be improved continuously in line with current developments in science and technology. This competition strengthened when the industrial revolution 4.0 was introduced first at an industry exhibition in the city of Hannover, Germany, which was marked by advances in computer and robot technology [3].

The competitive advantage possessed by universities is closely related to the fulfillment of customer demands and expectations. This condition 
requires universities to provide excellent service and be able to foster loyalty in providing services [4]. This service can provide customer satisfaction that can influence student and community behavior towards educational institutions [5]. Good college services are part of marketing in creating customer satisfaction, so students can easily access college services effectively and efficiently [6]. Existing services in higher education can be used as part of marketing education in improving the competitiveness of higher educations. This service excellence is also part of efforts to improve the quality of higher education and student satisfaction [7]. Student satisfaction is the first step to create competitiveness and market higher education so that it is in demand by the community and education stakeholders.

Marketing strategies are designed to influence customers to have a positive perception of products and services, even interested in trying products and services. Competitive value marketing strategy, universities know customers who will buy their products, things that attract customers to like products and services, what criteria are considered by customers in purchasing products and services, how customers obtain information related to products and services. The results showed that the external communication of educational institutions is needed in marketing education closely related to placement in the market [8]. Marketing education is closely related to programs, prices, promotions, places, human and non-human resources in both physical and process forms. The results showed that physical facilities and excellence can be used as the most important marketing strategy, while the price is something that is not important in choosing an educational institution [9]. Higher education requires marketing in offering educational services to the community. This is done by providing universities that can increase satisfaction through emotional touch, the costs incurred by the community do not become a benchmark for satisfaction, the community considers the perceived emotional experience to create positive experiences and the community becomes loyal to the college.

College marketing has experienced a revolution in an interesting study to discuss. Higher education must have educational staff in the field of marketing. Many marketing innovations are done to attract customers. The marketing is doing innovation in the context of market education to produce inputs that are by predetermined target standards and get quality inputs to win in higher education competition. Universities must be innovative to build and maintain a competitive advantage in the current era of global competition [10]. Innovations in marketing educational institutions can be carried out by developing university libraries by using e-books [11]. Innovation in marketing colleges requires the ability to learn continuously for each individual in developing higher education so that they are in demand by education customers. This is consistent with the results of research that explains that the knowledge held by learning outcomes by marketing personnel influences in making marketing innovations [12]. Innovations can be made in the field of education services because education services have a strong influence on the competitive advantage and marketing performance of universities [13]. College marketing innovation can develop rapidly through changes and developments in global conditions and the everchanging needs of customers. This condition requires adaptive learning ability to be able to increase marketing innovation in education services and customer needs well so that higher education is in demand by many education customers.

The marketing strategy of the university has been carried out professionally with a variety of media used, such as electronic media, multimedia, internet, posting brochures and pamphlets at strategic places that are widely known and visited by many people. This is done to promote the quality of higher education and win professional competitiveness. College customers no longer look at the distance traveled from home to college and education staff, but rather the thoughts of the customers. This can be done by universities to win competitiveness by occupying an important position in the minds of customers [14]. Marketing of higher education services can also be implemented by paying attention to tuition fees, graduation rates, and labor market effects as a marketing strategy and increasing interest in higher education [15]. This is very important to be considered by universities in meeting the demands and needs of customers so that education customers can provide strong support and have an interest in using higher education services.

Higher education which positions itself as a superior university certainly has a more appropriate bargaining position. However, in reality the trends of college customers do not see the position, rather consider how much the results obtained from higher education products and services by spending customers to utilize products and services. This is important to be considered by universities so that they can provide educational services with facilities and infrastructure that can support the learning process. Service facilities and infrastructure as well as academic processes can make universities have high competitiveness. The competitiveness of higher education is largely determined by the ability of higher education leaders to increase competitive advantage. The results showed that higher education leadership, lecturer performance, and academic culture had a positive effect on increasing the competitiveness of higher education [16]. This condition shows that tertiary institutions must be able to improve their processes and commitments in improving quality and competitiveness so that it becomes easier to market higher education services. 
College marketing can be implemented using experiential marketing strategies. This marketing strategy is assessed based on customer experience in using products to make customers satisfied [17, 18]. Every customer has an emotional value to the satisfaction of existing services in college. Good emotional experience and give satisfaction to customers can form positive perceptions so that the growing trustworthiness of the products produced by universities. Consumer direct experience is the first effective factor informing people's attitudes towards products and services [19, 20]. Experience is the best way to market a product because it has a positive influence on consumers [21]. This marketing strategy can be carried out by universities engaged in services to provide the best experience for every education stakeholder. Direct and indirect customer experience can help market educational institutions based on positive perceptions held by customers. The competitive advantage of tertiary institutions occurs continuously so that each tertiary institution always innovates and improves academic and non-academic services so that customers become satisfied and provide support to tertiary institutions.

Experiential, marketing that is applied by universities can deliver customers to gain experience through the five senses directly. Since marketing has a significant influence on customer interests [22]. What is seen directly by the customer can strengthen customer interest in the product [23]. Since marketing is needed by universities so that customers can see and take action directly on stimulants obtained from college conditions. Since marketing is used to differentiate products or services from college competitors by providing motivation and attracting attention through things that can enhance the impression that education customers cannot forget. The emotional connection of customers with the places visited is very important in carrying out marketing [24]. Higher education as an organization engaged in services must be able to create situations and conditions for customers to obtain an interesting and memorable emotional experience so that customers keep remembering and have a positive perception of the college.

Feel marketing is a strategy and implementation in binding customers to feel happy with a product in college. Feeling happy can increase customer loyalty to the organization [25]. Feeling happy about tertiary institutions because of a good learning system, satisfying academic services, and the existence of good and supportive interpersonal relationships in creating a dynamic and comfortable work climate are elements that can be used as the marketing of higher education institutions so that customers have a sense of pleasure towards the organization. Feeling happy because the services provided are also related to customer satisfaction that can help in carrying out marketing services [26]. Feel marketing can be pursued successfully by creating feelings through direct experience of service users towards the entire program of activities and services in higher education. Higher education must have a competitive advantage to be able to compete and market educational services that are in demand by customers. Feel marketing influences customer satisfaction and customer loyalty [27]. This shows that the positive experience that is owned by the customer towards the university can provide trust to the customer, the customer experiences, and directly experiences the conditions that occur in the college. This condition can be used as an effort to market educational services with due regard to customer satisfaction.

Think marketing is a marketing method that encourages customers to think creatively about superior products and their marketing strategies to be competitive and competitive. Improving performance and developing new products with innovation can improve an organization's competitiveness [28]. Customers are encouraged to think about innovations and superior programs created by universities. The vision, mission, and goals of the tertiary institution serve as a force that encourages the entire academic community to create creativity and innovation to make it happen. Customers can think and analyze the advantages possessed by universities based on their vision, mission, goals, and strategic programs owned by universities. Innovation and excellence owned by companies and organizations have a positive influence on marketing and competitiveness [29]. Promotion and marketing are directed to form positive perceptions of universities. This must be carried out with authentic data and programs that attract public interest in higher education.

Marketing education services also require the ability and experience of personnel to think creatively and be able to create experiences related to students accepted into college. Experience can be used as a basis for thinking and doing better in carrying out marketing [30]. Higher education institutions as educational institutions engaged in services have strategic policies in improving quality and competitiveness so that they are in demand by education customers. Strategic policies can be an innovation program in marketing activities to gain customer trust. Making interesting activities in marketing can help in building a better perception of interactively and attracting customer satisfaction in creating competitiveness [31]. Higher education can also create activities that involve the general public at large with innovative and interesting programs so that they are interested in and provide support to universities. The support given by the community at large can increase the competitiveness of higher education to be able to progress and develop to become better and competitive. Experience can be used as a basis for continuous improvement in marketing and developing universities to be better and more 
competitive. Experiential marketing can be used as a college marketing strategy that puts forward the formation of positive thoughts in the service sector and effective service delivery in every organization [32, 33]. Experimental marketing focuses on the customer's feelings, feel, think, act, and relate their experience [34]. Experiential marketing is very important to be applied to universities that want to increase competitiveness that is in the declining stage, make a comparison of the output of universities with competitor output, immediately take action to create culture and identity, innovate and influence customers who have high loyalty so that universities can inform the quality of tertiary institutions and can compete with other tertiary institutions.

Competition among universities which is increasingly competitive makes customers a reliable voter. Higher education must be able to meet customer needs as the key to winning the competition. Among them is fulfilling customer desires so that customers get satisfaction. Customer satisfaction can build the image of tertiary institutions, so it can also be seen as the quality of tertiary institutions that prioritizes community needs. Quality is a dynamic idea that can be used as a relative counsel [35]. Quality has two aspects that need to be considered, namely: (1) adjusting to specifications by the objectives and quality benefits, (2) meeting the needs of customers. Improving the quality of higher education can refer to changes in lecturer quality and academic quality [36]. The quality of lecturers can be seen from their competencies, mastery of the material, methods, self-control, and discipline. Academic quality is seen in the curriculum and infrastructure that can support learning activities. Based on the explanation and description above, this study will examine the effects of experiential marketing on college competitiveness. Higher education competitiveness needs to be improved continuously to be able to gain the trust of education customers.

\section{RESEARCH METHODS}

This study aims to examine in depth the influence of experiential marketing which is described in the form of sense, feel, think, act, and relate marketing to the competitiveness of Islamic tertiary institutions in East Java Indonesia. To achieve these objectives, survey techniques are used to collect research data using a questionnaire that has proven its validity and reliability. The questionnaire was compiled based on a theory developed by Schmitt [37] about experiential marketing which was translated into the components of sense, feel, think, act, and relate marketing informing higher education organizations to have competitiveness. The research data was taken from 200 education staff from IAIN Tulungagung and UIN Malang who were the samples of this study. Data collection was carried out with random sampling techniques at each college [38].

This study uses the Structural Equation Model (SEM) approach to examine the influence of research variables in a model developed in this study. The data that has been collected is first analyzed using the descriptive analysis to determine the condition of each foreign research variable. The stages of SEM analysis in this study were carried out with the following steps:

\section{Validity Factor Test or CFA Test (Confirmatory Factor Analysis) \\ CFA test is used to reduce indicators on} research variables. Indicators used as a measure of research variables are indicators that have $p$-value $<0.05$ and loading factor $>0.5$, while indicators that have $p$ value $>0.05$ and loading factor $<0.5$ are eliminated from the model. CFA test uses the AMOS program, this test is carried out 2 times, namely on the Exogenous variable and the Endogenous variable. At the Regression Weight output, at the P-value (probability), if the value is not significant (above 0.05) then the indicator must be deleted [39]. And in the Standardized Regression Weight, the loading factor value (Estimate) above 0.5 indicates that the indicator can explain the existing construct [40,41].

\section{Research Hypothesis Test}

Research hypothesis testing using SEM models in this study was carried out with several test stages based on the development of the theory. The theoretical model developed in this study can be explained in the form of an image as follows:

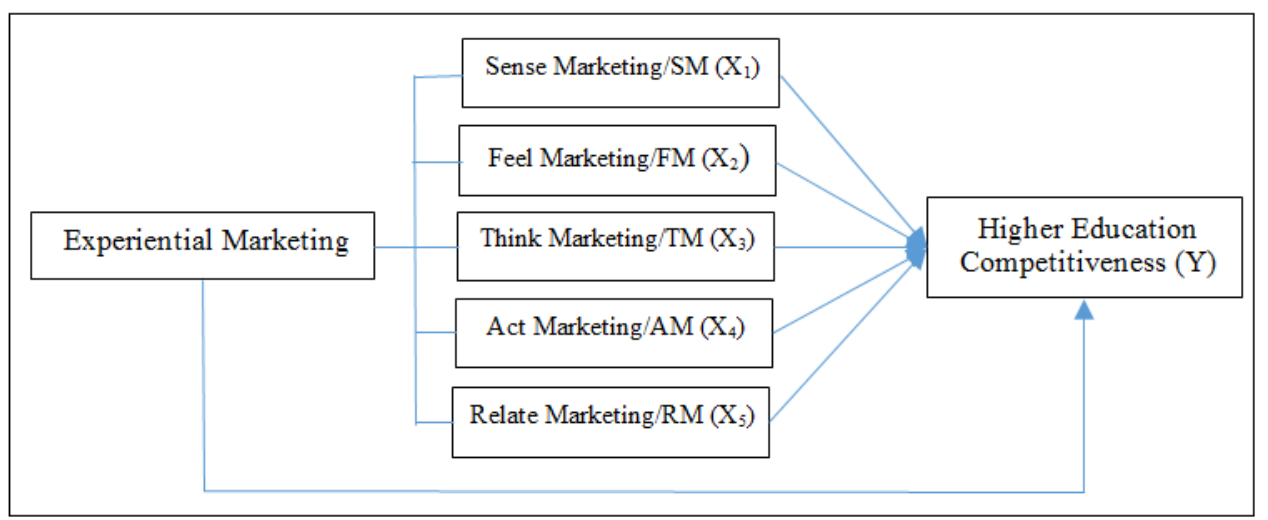

Fig-1: Theoretical Research Model 
The picture above shows that in this study consists of 2 constructs, namely: (1) the construction of exogenous variables consisting of sense marketing (SM), feel marketing (FM), think marketing (TM), act marketing (AM), and relate marketing (RM), (2) the construct of endogenous variables is the competitiveness of higher education.
The theoretical model that has been built in the first stage will be illustrated in an SEM model diagram that can make it easier to see the causal relationships to be tested. The relationship between constructs is expressed through arrows, straight arrows show a direct causal effect between one contract and the other, while the curved lines between the constructs with arrows at each end show the correlation between constructs. The intended SEM model diagram is as follows:

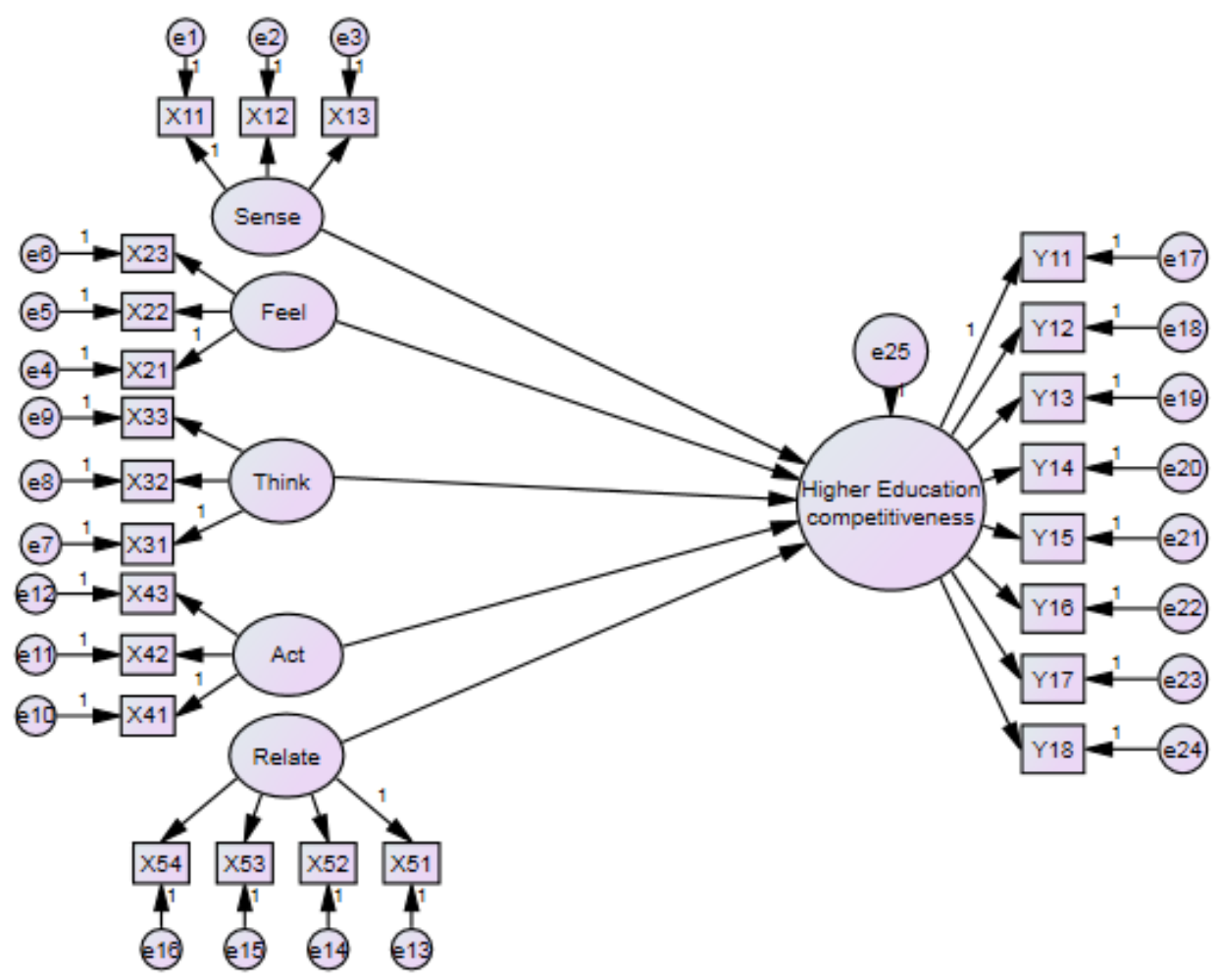

Fig-2: Research Model for Structural Equational Model (SEM)

Some assumptions must be met in testing the SEM model, namely: the use of parametric statistics or the so-called multivariate normality assumption. A normality test is done to see the level of normality of the data used or to find out data that is normally distributed or data that is not normally distributed. Normal or not data distribution can be seen from the value of the critical ratio (CR) in skewness and kurtosis. The CR comparison figure is the $\mathrm{Z}$ number. Generally the $99 \%$ confidence level is used, at the confidence level the significance level is 0.01 or $1 \%$, the $\mathrm{Z}$ number is 2.58. Thus a data distribution is said to be normal if the CR skewness or CR kurtosis number is between 2.58 to 2.58. But if the numbers are below -2.58 (eg -4 , -5 , etc.) or above 2.58 , the data distribution can be said to be abnormal [42].
The goodness of fit test is used to determine how precisely manifest variables can explain the latent variables (constructs) contained in this study. If overall a structural model can be considered fit, the next process is to see whether there is a significant effect between the independent variable and the dependent variable. Testing this hypothesis is done by looking at the estimated results of the research model (output regression weight).

\section{RESULT AND DISCUSSION Descriptive Analysis \\ Descriptive analysis results of college competitiveness are measured from 8 research statements, the following is a description of college competitiveness:}


Table-1: Average Choices of Respondents on Variable Competitiveness of Higher Education

\begin{tabular}{|c|c|c|c|c|}
\hline \multicolumn{5}{|c|}{ Competitiveness of Higher Education } \\
\hline Number & Research Statement & Mean & Percentage & Classification \\
\hline 1 & Tuition fees are relatively affordable & 3.23 & 80.75 & Good \\
\hline 2 & Education staff productivity & 3.2 & 80 & Good \\
\hline 3 & Interesting study programs for education customers & 3.3 & 82.5 & Good \\
\hline 4 & The study program is by the needs of education service users & 3.325 & 83.125 & Good \\
\hline 5 & The duration of study of students on time & 3.195 & 79.875 & Good \\
\hline 6 & Curriculum according to customer needs & 3.13 & 78.25 & Good \\
\hline 7 & Has many study program choices & 3.175 & 79.375 & Good \\
\hline 8 & $\begin{array}{l}\text { There are facilities and motivation of students to complete } \\
\text { their studies on time }\end{array}$ & 3.23 & 80.75 & Good \\
\hline Average & & 3.223 & 80.575 & Good \\
\hline
\end{tabular}

Based on the above table, if it is seen from the mean value or from the statement that gets the highest score is 3,325 with good criteria, namely study programs in Higher Education by the needs of users of educational services. While the lowest average value obtained with a value of 3.13 , this value is in good criteria that every study program has a curriculum that is by the needs of customers and the education service user community. This reflects that the study programs in Higher Education are by the needs of education service users and have a mapping of study programs that are attractive to education customers.

The results of the descriptive SM analysis are measured from 3 research statements that can be explained in the form of a table as follows:

Table-2: Respondents' Perceptions of SM Variables

\begin{tabular}{|l|l|l|l|l|}
\hline \multicolumn{5}{|c|}{ Sense Marketing (SM) } \\
\hline Number & \multicolumn{1}{|c|}{ Research Statement } & Mean & Percentage & Classification \\
\hline 1 & Have a building with a good design & 3.220 & 80.5 & Good \\
\hline 2 & $\begin{array}{l}\text { Study programs according to the interests and needs of the } \\
\text { community }\end{array}$ & 3.190 & 79.75 & Good \\
\hline 3 & It has a strategic location & 3.180 & 79.5 & Good \\
\hline Average & 3.197 & 79.925 & Good \\
\hline
\end{tabular}

Based on the table above if seen from the mean value or from the statement that gets the highest score is 3,220 with good criteria, namely the college has building facilities with good design. While the lowest average value of getting 3,180 with good criteria is that universities are in strategic locations. This reflects that the tertiary institution has building facilities with good design and the tertiary institution has a variety of interesting study programs and is by the interests and needs of educational customers.

The results of the FM descriptive analysis in this study were measured from 3 research statements that can be explained in the form of a table as follows:

Table-3: Respondents' Perception of FM Variables in Higher Education

\begin{tabular}{|l|l|l|l|l|}
\hline \multicolumn{5}{|c|}{ Feel Marketing (FM) } \\
\hline Number & \multicolumn{1}{|c|}{ Research Statement } & Mean & Percentage & Classification \\
\hline 1 & Study programs can increase the trust of education customers & 3.150 & 78.75 & Good \\
\hline 2 & Structuring the building has an appeal to customer education & 3.210 & 80.25 & Good \\
\hline 3 & Academic services & 3.370 & 84.25 & Very Good \\
\hline Average & 3.243 & 81.075 & Good \\
\hline
\end{tabular}

Based on the table above, it can be explained that the mean value of the research statement that gets the highest score is 3,370 with good criteria, namely the academic department provides excellent service to educational customers. While the lowest average value is at 3,150 with good criteria, namely the study program offered by Higher Education can increase the trust of education customers. This reflects that the academic department provides excellent service to education customers and the structuring of each faculty building can be a special attraction for education customers.

The results of the descriptive TM analysis are measured by 3 research statements that can be explained in the form of a table as follows: 
Table-4: Respondents' Perceptions of TM Variables in Higher Education

\begin{tabular}{|l|l|l|l|l|}
\hline \multicolumn{2}{|l|}{ Think Marketing (TM) } & Mean & Percentage & Classification \\
\hline Number & Research Statement & 3.350 & 83.75 & Good \\
\hline 1 & Attitudes of educational staff to customers & 3.200 & 80 & Good \\
\hline 2 & Promotion of study programs and expertise specifications & 3.260 & 81.5 & Good \\
\hline 3 & Choice of study programs can attract customer interest & 3.270 & 81.75 & Good \\
\hline Average & &
\end{tabular}

Based on the table obtained the mean value of the research statement by obtaining the highest score of 3,350 , these results are in good condition. This means that education personnel can show a caring attitude towards education customers. The lowest average score is at 3,200 with good criteria, which means that universities can promote the study programs and expertise specifications of each program well. The results of this study indicate that education personnel has a caring attitude towards education customers and the choice of study programs offered can attract the interest of prospective education customers.

The results of the descriptive analysis of the AM are measured by 3 research statements that can be explained in the following table:

Table-5: Respondents' Perceptions of Variable AM in Higher Education

\begin{tabular}{|l|l|l|l|l|}
\hline \multicolumn{5}{|c|}{ Act Marketing (AM) } \\
\hline Number & \multicolumn{1}{|c|}{ Research Statement } & Mean & Percentage & Classification \\
\hline 1 & $\begin{array}{l}\text { Information and activities of Higher Education can be } \\
\text { accessed by customers }\end{array}$ & 3.140 & 78.5 & Good \\
\hline 2 & Hold scientific activities involving customers & 3.460 & 86.5 & Very Good \\
\hline 3 & Islamic activities that benefit customers & 3.190 & 79.75 & Good \\
\hline Average & 3.263 & 81.575 & Good \\
\hline
\end{tabular}

Based on the table above that gets the highest mean value is 3,460 with very good criteria, meaning that universities often hold scientific activities involving educational customers. While the lowest average values obtained with the results 3,140 , these results indicate the criteria of good. This means that education customers can access information and activities held by higher education through the website that is easily available at any time. The results of this study indicate that tertiary institutions often hold scientific activities involving educational customers and tertiary institutions hold activities that can be directly benefited by education customers.

The results of the descriptive analysis of the RM variable can be measured based on 4 research statements that can be explained as follows:

Table-6: Respondents' Perception of RM Variables in Higher Education

\begin{tabular}{|l|l|l|l|l|}
\hline \multicolumn{2}{|l|}{ Relate Marketing (RM) } \\
\hline Number & Research Statement & Mean & Percentage & Classification \\
\hline 1 & $\begin{array}{l}\text { University Alumni provide recommendations to } \\
\text { prospective customers }\end{array}$ & 3.200 & 80 & Good \\
\hline 2 & Organizing educational festivals can attract customers & 3.060 & 76.5 & Good \\
\hline 3 & Involving customers in the implementation of activities & 3.290 & 82.25 & Good \\
\hline 4 & Good communication with education customers & 3.170 & 79.25 & Good \\
\hline Average & 3.180 & 79.5 & Good \\
\hline
\end{tabular}

Based on the table above obtained the mean value with the highest score of 3,290 with good criteria, meaning that universities involve education customers in each of their activities. While the lowest average value is at 3.060 with good criteria, the intention is that educational festivals held by universities can attract the interest of education customers. The results of this study indicate that universities in carrying out activities involving education customers and graduates provide recommendations to prospective education customers to be able to study at graduate colleges.

\section{CFA (Confirmatory Factor Analysis) Test or Test Validity Constructions \\ CFA test on exogenous variables}

The exogenous variable model in this research consists of sense, feel, think, act, and relate marketing variables. This exogenous variable model can be explained in the form of an image as follows: 


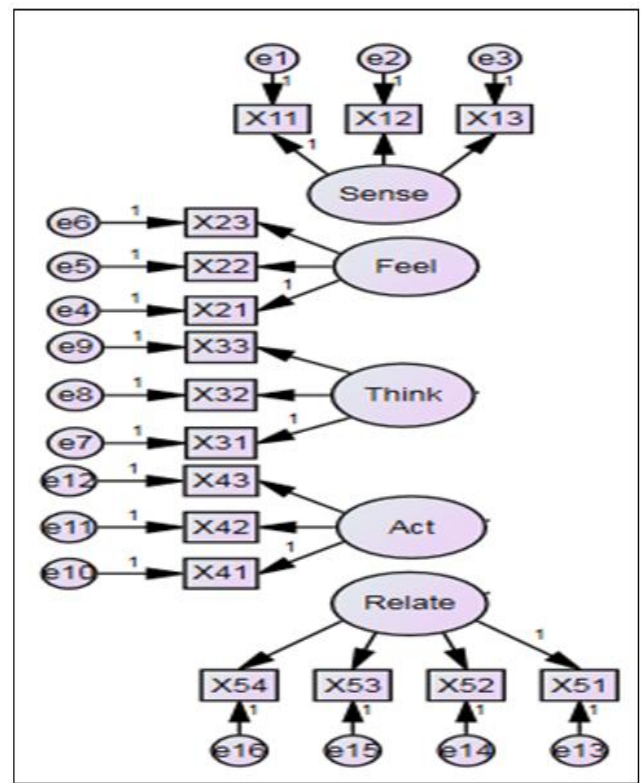

Fig-3: Exogenous Variable Model of Experiential Marketing

Exogenous variable CFA (Confirmatory Factor Analysis) test results about experiential marketing which are described in the form of sense, feel, think, act, and relate marketing in this study can be explained in the form of a table as follows:

Table-7: CFA test results on exogenous variables about Experiential Marketing

\begin{tabular}{|l|l|l|l|l|l|l|}
\hline \multicolumn{6}{|c|}{ Maximum Likelihood Estimates Regression Weights: (Group number 1 - Default model) } \\
\hline & & & Estimate & S.E. & C.R. & P \\
\hline X11 & $<---$ & SM & 1.000 & & & \\
\hline X12 & $<---$ & SM & 1.307 & .199 & 6.559 & $* * *$ \\
\hline X13 & $<---$ & SM & 1.635 & .251 & 6.508 & $* * *$ \\
\hline X21 & $<---$ & FM & 1.000 & & & \\
\hline X22 & $<---$ & FM & 1.625 & .449 & 3.615 & $* * *$ \\
\hline X23 & $<---$ & FM & .753 & .156 & 4.834 & $* * *$ \\
\hline X31 & $<---$ & TM & 1.000 & & & \\
\hline X32 & $<---$ & TM & 1.290 & .237 & 5.453 & $* * *$ \\
\hline X33 & $<---$ & TM & .779 & .140 & 5.543 & $* * *$ \\
\hline X41 & $<---$ & AM & 1.000 & & & \\
\hline X42 & $<---$ & AM & .924 & .157 & 5.887 & $* * *$ \\
\hline X43 & $<---$ & AM & .710 & .114 & 6.230 & $* * *$ \\
\hline X51 & $<---$ & RM & 1.000 & & & \\
\hline X52 & $<---$ & RM & 1.568 & .168 & 9.351 & $* * *$ \\
\hline X53 & $<---$ & RM & 1.273 & .147 & 8.691 & $* * *$ \\
\hline X54 & $<---$ & RM & 1.205 & .145 & 8.301 & $* * *$ \\
\hline
\end{tabular}

Based on the test results above shows the probability value by obtaining a p-value which indicates ***. This means that the acquisition of the probability value shows $<0.05$. This means that the CFA test results on the indicators in this study were declared valid. The next step is to carry out a test using standardized Regression Weights which is explained in the form of a table as follows: 
Table-8: Standardized Regression Weights: (Group number 1 - Default model)

\begin{tabular}{|l|l|l|l|}
\hline & & & Estimate \\
\hline X11 & $<---$ & SM & .609 \\
\hline X12 & $<---$ & SM & .727 \\
\hline X13 & $<---~$ & SM & .748 \\
\hline X21 & $<---$ & FM & .590 \\
\hline X22 & $<---$ & FM & .878 \\
\hline X23 & $<---$ & FM & .577 \\
\hline X31 & $<---$ & TM & .681 \\
\hline X32 & $<---$ & TM & .729 \\
\hline X33 & $<---~$ & TM & .552 \\
\hline X41 & $<---~$ & AM & .647 \\
\hline X42 & $<---$ & AM & .820 \\
\hline X43 & $<---$ & AM & .572 \\
\hline X51 & $<---$ & RM & .655 \\
\hline X52 & $<---$ & RM & .813 \\
\hline X53 & $<---$ & RM & .807 \\
\hline X54 & $<---~$ & RM & .737 \\
\hline
\end{tabular}

Based on the test results above shows that the standardized regression weight at the estimated value gets the value of $>0.5$. Thus everything contained in this study is declared valid, meaning that all indicators of research statements that have been formulated in this study can explain the existing construction.

\section{CFA test on endogenous variables}

The endogenous variable model in this study consists of one dependent variable, namely college competitiveness. The endogenous variable model in this study can be explained as follows:

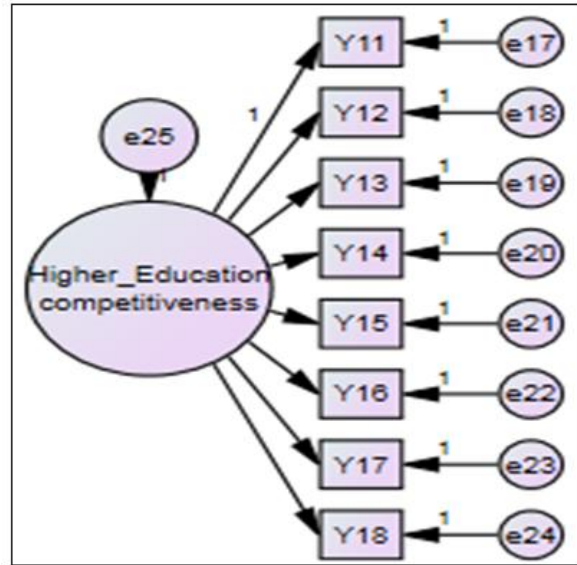

Fig-4: Endogenous Variables in the Research Model of Higher Education Competitiveness

CFA (Confirmatory Factor Analysis) test results of endogenous variables about the competitiveness of tertiary institutions can be explained in the form of a table as follows:

Table-9: CFA test results on endogenous variables About Higher Education Competitiveness

\begin{tabular}{|l|l|l|l|l|l|l|}
\hline \multicolumn{6}{|c|}{ Maximum Likelihood Estimates Regression Weights: (Group number 1 - Default model) } \\
\hline & & & Estimate & S.E. & C.R. & P \\
\hline Y1 & $<---$ & Competitiveness & 1.000 & & & \\
\hline Y2 & $<---$ & Competitiveness & 1.202 & .175 & 6.859 & $* * *$ \\
\hline Y3 & $<---$ & Competitiveness & 1.263 & .177 & 7.147 & $* * *$ \\
\hline Y4 & $<---$ & Competitiveness & .949 & .150 & 6.342 & $* * *$ \\
\hline Y5 & $<---$ & Competitiveness & 1.146 & .167 & 6.878 & $* * *$ \\
\hline Y6 & $<---$ & Competitiveness & 1.640 & .215 & 7.636 & $* * *$ \\
\hline Y7 & $<---$ & Competitiveness & 1.721 & .221 & 7.777 & $* * *$ \\
\hline Y8 & $<---$ & Competitiveness & 1.476 & .197 & 7.501 & $* * *$ \\
\hline
\end{tabular}

Output Regression Weight is shown at the pvalue, if the p-value is not significant (the value is above 0.05 ) then the indicators in this study must be deleted. The results of this study indicate that all probability values show a *** sign which means the results of this analysis are significant at the level of
0.001 or also less than 0.05 . The results of this analysis when viewed from the Regression Weight are all valid indicators, but significant results do not necessarily give a high loading factor (Estimate value) above 0.5. The next step is to carry out a CVA test with standardized Regression weights as contained in the following table:

Table-10: Endogenous Variable CFA Test Results on Higher Education Competitiveness

\begin{tabular}{|l|l|l|l|}
\hline \multicolumn{3}{|c|}{ Standardized Regression Weights: (Group number 1 - Default model) } \\
\hline & & & Estimate \\
\hline Y1 & $<---$ & Competitiveness & .580 \\
\hline Y2 & $<---$ & Competitiveness & .632 \\
\hline Y3 & $<---$ & Competitiveness & .641 \\
\hline Y4 & $<---$ & Competitiveness & .550 \\
\hline Y5 & $<---$ & Competitiveness & .617 \\
\hline Y6 & $<---$ & Competitiveness & .743 \\
\hline Y7 & $<---$ & Competitiveness & .767 \\
\hline Y8 & $<---$ & Competitiveness & .725 \\
\hline
\end{tabular}


Test results using the Standardized Regression Weight if the value of the loading factor (Estimate) is above 0.5 , then the test results of the indicators in the study have been able to explain the existing construct. Based on the test results in this study, it can be stated that all indicators contained in endogenous variables about the competitiveness of higher education institutions can be said to be valid so that these indicators are suitable for future research and test models.

\section{Model Assumption Test}

Several assumptions must be met in carrying out the SEM analysis test model, the intended assumptions are as follows:

\section{Multivariate Normality Test}

Estimation using the Maximum Likelihood (ML) method requires an assumption that must be met, that is, the distribution of observed variables to normal multivariate. Evaluation of multivariate normality is done by using the criterion ratio $(\mathrm{CR})$ of multivariate in kurtosis if it is in the range of -2.58 to 2.58 , it means that the data are normally distributed multivariate. The following are the results of normality test data on the model:

Table-11: Data Normality Test Results about Experiential Marketing and Higher Education Competitiveness

\begin{tabular}{|l|l|l|l|l|l|l|}
\hline Assessment of normality (Group number 1) \\
\hline Variable & Min & Max & Skew & C.R. & Kurtosis & C.R. \\
\hline Y18 & 1.000 & 4.000 & -.859 & -4.959 & -.248 & -.716 \\
\hline Y17 & 1.000 & 4.000 & -.911 & -5.260 & -.302 & -.873 \\
\hline Y16 & 1.000 & 4.000 & -.915 & -5.282 & -.131 & -.377 \\
\hline Y15 & 1.000 & 4.000 & -.828 & -4.781 & .230 & .664 \\
\hline Y14 & 1.000 & 4.000 & -.967 & -5.585 & .597 & 1.723 \\
\hline Y13 & 1.000 & 4.000 & -1.145 & -6.609 & .630 & 1.819 \\
\hline Y12 & 1.000 & 4.000 & -.867 & -5.004 & .209 & .604 \\
\hline Y11 & 1.000 & 4.000 & -.689 & -3.979 & .009 & .027 \\
\hline X54 & 1.000 & 4.000 & -.842 & -4.859 & -.163 & -.471 \\
\hline X53 & 1.000 & 4.000 & -.874 & -5.049 & -.376 & -1.085 \\
\hline X52 & 1.000 & 4.000 & -.832 & -4.802 & -.584 & -1.685 \\
\hline X51 & 1.000 & 4.000 & -.902 & -5.205 & .251 & .723 \\
\hline X43 & 1.000 & 4.000 & -.733 & -4.231 & .161 & .465 \\
\hline X42 & 1.000 & 4.000 & -1.264 & -7.296 & 1.481 & 4.274 \\
\hline X41 & 1.000 & 4.000 & -.894 & -5.161 & -.222 & -.641 \\
\hline X33 & 2.000 & 4.000 & -.334 & -1.926 & -.761 & -2.196 \\
\hline X32 & 1.000 & 4.000 & -.813 & -4.695 & .028 & .080 \\
\hline X31 & 1.000 & 4.000 & -.950 & -5.486 & 1.103 & 3.183 \\
\hline X23 & 1.000 & 4.000 & -.750 & -4.331 & .555 & 1.603 \\
\hline X22 & 1.000 & 4.000 & -.648 & -3.740 & -.096 & -.277 \\
\hline X21 & 1.000 & 4.000 & -.812 & -4.687 & .162 & .466 \\
\hline X13 & 1.000 & 4.000 & -.921 & -5.315 & -.213 & -.615 \\
\hline X12 & 1.000 & 4.000 & -.721 & -4.162 & .023 & .066 \\
\hline X11 & 1.000 & 4.000 & -.843 & -4.864 & .975 & 2.815 \\
\hline Multivariate & & & & & 120.284 & 24.076 \\
\hline & & & & & &
\end{tabular}

Based on the above output, it can be seen as a whole (multivariate) showing a normal data distribution, because the multivariate number of -.109 is below 2.58. Data normality testing is done by observing $\mathrm{CR}$ values in a multivariate manner. If the multivariate critical ratio value is between -2.58 to 2.58 , then the data can be categorized as in a normal distribution. Based on the results of the test data in this study it can be seen that the multivariate CR value is 120,284 . These results indicate the acquisition of a value higher than the value between -2.58 to 2.58 . Thus it can be concluded that the assumption of multivariate normality in this study has not been fulfilled. Although the calculation of the analysis results concludes thus, the Central Limit Theorem states that the normality assumption is not too critical for large samples [43]. Therefore this research model can still be continued to carry out the next model test.

\section{The Goodness of fit test (Model Feasibility Test)}

At this stage, testing of the suitability of the model against various criteria contained in this study. The following is explained in the form of a Goodness of fit assessment criteria table with the following results: 
Table-12: Goodness of fit test results

\begin{tabular}{|l|l|l|l|}
\hline Goodness of Fit & Cut off value & Results & Decision \\
\hline Chi Square Probability & $\geq 0,05$ & 0,000 & Bad Fit \\
\hline CMIN/DF & $\leq 2,00$ & 9.689 & Bad Fit \\
\hline GFI & $\geq 0,90$ & 0,544 & Bad Fit \\
\hline AGFI & $\geq 0,90$ & 0,446 & Bad Fit \\
\hline CFI & $\geq 0,90$ & 0,504 & Bad Fit \\
\hline TLI & $\geq 0,90$ & 0,408 & Bad Fit \\
\hline NFI & $\geq 0,90$ & 0,445 & Bad Fit \\
\hline IFI & $\geq 0,90$ & 0,507 & Marginal Fit \\
\hline RMSEA & $\leq 0,08$ & 0,209 & Bad Fit \\
\hline RMR & $\leq 0,05$ & 0,246 & Bad Fit \\
\hline
\end{tabular}

From the above output, it can be seen that the indicator value does not meet the minimum 5 good fit indicators. So overall the model cannot be said to be fit, with this the model will be modified. Modification of the model is done by connecting with lines or covariation between error variables in the model, according to those recommended by AMOS (on the Modification Indices output). The Goodness of fit test results after model modification is explained in the following table

Table-13: The goodness of fit test results after modifying the model

\begin{tabular}{|c|c|c|c|}
\hline Goodness of Fit & Cut off value & Results & Decision \\
\hline Chi Square Probability & $\geq 0,05$ & 0,000 & Bad Fit \\
\hline CMIN/DF & $\leq 2,00$ & 1,468 & Good Fit \\
\hline GFI & $\geq 0,90$ & 0,828 & Marginal Fit \\
\hline AGFI & $\geq 0,90$ & 0,775 & Bad Fit \\
\hline CFI & $\geq 0,90$ & 0,937 & Good Fit \\
\hline TLI & $\geq 0,90$ & 0,926 & Good Fit \\
\hline NFI & $\geq 0,90$ & 0,830 & Marginal Fit \\
\hline IFI & $\geq 0,90$ & 0,939 & Good Fit \\
\hline RMSEA & $\leq 0,08$ & 0,069 & Good Fit \\
\hline RMR & $\leq 0,05$ & 0,039 & Good Fit \\
\hline
\end{tabular}

Based on the results of the analysis in the table above, it can be stated that 6 indicators indicate good fit so that the indicator meets the minimum requirements 5 indicators are Good fit, therefore it can be concluded that the overall model in this study can be declared fit or have fulfilled the model analysis requirements.

\section{Model Hypothesis Test}

Testing this hypothesis is carried out by looking at the estimated results of the research model. Next, the researcher wants to see the significance between the research variables which can be explained in the following table:

Table-14: Effect Test Results between Research Variables

\begin{tabular}{|l|l|l|l|l|l|l|}
\hline & & & Estimate & S.E. & C.R. & P \\
\hline Competitiveness & $<---$ & SM & -.001 & .010 & -.055 & .956 \\
\hline Competitiveness & $<---$ & FM & .006 & .009 & .693 & .489 \\
\hline Competitiveness & $<---$ & TM & .185 & .047 & 3.923 & $* * *$ \\
\hline Competitiveness & $<---$ & AM & .277 & .036 & 7.686 & $* * *$ \\
\hline Competitiveness & $<---$ & RM & .336 & .041 & 8.102 & $* * *$ \\
\hline
\end{tabular}

Based on the above hypothesis test, the results of this study can be concluded that: (1) there is no influence between SM on the competitiveness of Islamic Universities in Indonesia. This is because the probability value is more than $0.05(0.956>0.05)$, (2) there is no influence between FM to the competitiveness of Islamic Universities in Indonesia. This is because the Probability value is higher than 0.05 (0.489> 0.05), (3) there is a significant influence between TM on the competitiveness of Islamic Universities in Indonesia. This is indicated by the acquisition of a probability value of less than 0.05 $(0,000<0.05)$, (4) there is a significant influence between AM on the competitiveness of Islamic Universities in Indonesia. This is because there is a probability value of less than $0.05(0,000<0.05)$, and
(5) there is a significant influence between RM to the competitiveness of Islamic Higher Education in Indonesia as indicated by the acquisition of a probability value of less than $0.05(0,000<0.05)$.

\section{DISCUSSION}

The Effect of SM on the Competitiveness of Universities

The application of SM in educational organizations is intended to create an attraction for education customers with their sense of sight to create a sensory experience through sight, sound, touch, taste, and smell. The results of this study indicate that sense marketing does not affect the competitiveness of Islamic tertiary institutions in Indonesia. Based on these findings it is suspected that sense marketing has not 
been implemented well in Indonesian Islamic tertiary institutions. Future research needs to examine more deeply the implementation of marketing sense in tertiary institutions to know the reasons that indicate there is no influence between sense marketing with competitiveness. This finding does not support the results of previous studies which explain that SM influences customer satisfaction and loyalty [44, 45]. Customer satisfaction and loyalty are very important in improving the quality and competitiveness of higher education. Customer satisfaction shows the fulfillment of customer expectations and needs. These hopes and needs become a program developed in educational institutions so that universities can continuously improve quality and competitiveness. Quality improvement is the key to the success of tertiary institutions to gain customer support and interest in competency products developed by tertiary institutions. Ideally, good SM can be used to increase customer interest and attractiveness to tertiary institutions, because with this strategy tertiary institutions can innovate strategic programs that become the core value of tertiary institutions, this can also be used to motivate users and improve values and competency product standards developed in educational institutions. SM requires an understanding of how to achieve a sensory impact on superior programs developed by universities. Flagship superior programs can be used to improve quality and competitiveness and attract customer interest [46]. The purpose of developing marketing sense is to create aesthetic pleasure, excitement, beauty, and satisfaction through the sensory stimulation of customers towards universities [47, 48]. SM can be used by universities to differentiate themselves with competency products developed by other universities, motivate customers and prospective customers to be interested in excellent programs developed by universities, and can also be used to provide added value to customers and education stakeholders.

\section{The Effect of FM on Higher Education Competitiveness}

The results of this study indicate that FM does not affect the competitiveness of higher education. The findings of this study need a deeper study of future research. This is because previous research findings provide an explanation that feels marketing has a significant relationship with customer satisfaction and loyalty [49, 50]. Ideally feel marketing is very important in marketing higher education to be in demand by customers and education stakeholders. Making customers feel they own, care for, maintain, and empathize with educational institutions must be pursued continuously in the organizational system of educational institutions. Making the feelings and emotions of education customers so that they have a sense of pride in the tertiary institution must be pursued throughout the entire process in the tertiary institution. The pride will be obtained by the customer if the university can show excellence and achievement that can boast all customers and education stakeholders. This condition must be a concern of higher education leaders to be able to take strategic decisions in achieving results that boast the entire academic community of higher education. In that context, what is needed by marketing feel is to create a stimulus that can trigger the emotions and willingness of customers to be interested and empathetic [51]. For this reason, universities must carry out continuous improvement and innovation in providing services and developing strategic programs that can attract the interests of education customers.

\section{The Effect of TM on Higher Education Competitiveness}

Think marketing in the higher education system can be carried out by involving educational stakeholders to solve the problems that exist in higher education institutions. Stakeholder involvement becomes very important to provide input in the development of higher education so that they can sustainably improve quality and competitiveness. Stakeholders can be invited by universities to provide input in the activities of creating the vision, mission, and goals of higher education, curriculum development, and other activities that require stakeholder input and opinions so that universities can meet the demands, expectations, and needs of educational customers. The results of this study indicate that think marketing has a significant influence on college competitiveness. The better it is to involve stakeholders in developing strategic higher education programs, the better it is to improve the quality and competitiveness of higher education. The results of this study provide support for previous research findings which explain that: think marketing influences customer satisfaction and customer loyalty [52-54]. Stakeholder involvement in solving problems that exist in tertiary institutions provides an opportunity for users of educational institutions to think critically and innovatively in maintaining and enhancing the competitiveness of higher education. Opinions and ways of thinking of customers need to be considered and responded positively to meet the needs and satisfaction of education customers. The competitive advantage of higher education can be enhanced through the involvement of thought from internal and external customers of higher education.

\section{The Effect of AM on Higher Education Competitiveness}

Improving the quality of higher education is carried out continuously to be able to meet customer needs. The development and needs of the community for the quality of education continue to increase along with the increase in science, culture, lifestyle, and people's expectations to be better. This condition can be responded positively by universities to be able to take concrete actions to meet customer demands and needs. Actual actions taken by universities are closely related to the innovation of education and learning programs 
and academic services. This innovation activity can influence customer actions both in the form of behavior and moral support to universities in improving quality and competitiveness. The results showed that act marketing in the fields of education, learning, and academic services can improve the competitiveness of higher education. The findings of this study reinforce previous studies in the field of act marketing that explain that act marketing conducted by companies can increase customer or customer satisfaction [55-57]. Efforts to influence customers can be carried out by direct interaction in the form of behavior or show other ways that can differentiate from other universities in carrying out an activity to the customer. Another way that can influence customers to take action is to provide positive support to a college. The key is that some improvements and updates can make customers more trustworthy and interested in higher education. Improving product quality based on marketing experience can improve competitiveness [58, 59]. Improvement and renewal of higher education strategic programs based on experience, strategic thinking, and interaction with customers through promotions supported by influential people can improve the competitiveness of higher education. If this is done well and responsibly, the tertiary institution has high competitiveness and has the support of all internal and external customers.

\section{The Effect of RM on Higher Education Competitiveness}

The marketing of higher education to attract public interest and educational stakeholders is a challenge that must be faced by higher education to be able to exist and have competitiveness in competition between higher education in obtaining high-quality inputs. This challenge must be faced with a variety of innovative educational and learning programs that are of interest to education stakeholders. Innovations owned by universities must be marketed to the public with appropriate marketing techniques and by the target. RM can be used as a strategy in marketing educational institutions so that they are in demand by the community. The results of this study indicate that there is a significant influence between RM and college competitiveness. Similar research also explains that RM influences customer satisfaction and loyalty [60-62]. Relate marketing is closely related to sense, feel, think, and act marketing. This linkage becomes very important to be developed in the marketing of educational services so that the brand image of tertiary institutions can be realized properly. A good image of higher education is needed so that public trust and education stakeholders increase. Increased public trust can increase the competitiveness of higher education institutions to become more competitive and attractive to many people. Experiential marketing in which there is also an RM factor can influence in building product quality [63]. Higher education can use this marketing strategy to gain customer trust and support for superior programs developed by universities in the whole process of education and learning. Relate marketing (RM) can connect universities and their superior programs with a broader social system in the form of associations and other organizations.

\section{REFERENCES}

1. Panday, R. (2018). Strategi peningkatan mutu perguruan tinggi untuk penguatan daya saing menghadapi masyarakat ekonomi Asia Tenggara: Studi Kasus.

2. Hutabarat, W. (2014). Effect of Organizational Culture, Organizational Structure, and Work Motivation on Job Satisfaction of Senior High School Teachers in Medan, Indonesia. International Journal of Sciences: Basic and Applied Research (IJSBAR), 16(01), 261-275.

3. Durmuş, A., \& Dağlı, A. (2017). Integration of vocational schools to industry 4.0 by updating curriculum and programs. International Journal of Multidisciplinary Studies and Innovative Technologies, 1(1), 1-3.

4. Noegroho, O. A. Suharyono, \& Kumadji, S.(2013). Pengaruh Experiential Marketing Dan Brand Trust Terhadap Kepuasan Pelanggan dan Loyalitas Pelanggan (Survei Pada Pelanggan KFC Cabang Kawi Malang). Jurnal Administrasi Bisnis, 6(2), 1-7.

5. Ham, L., \& Hayduk, S. (2003). Gaining competitive advantages in higher education: analyzing the gap between expectations and perceptions of service quality. International Journal of Value-Based Management, 16(3), 223242.

6. Kurniadi, D., \& Mulyani, A. (2016). Implementasi Pengembangan Student Information Terminal (SIT) Untuk Pelayanan Akademik Mahasiswa. Jurnal Algoritma, 13(2), 437-442.

7. Hanaysha, J. R., Abdullah, H. H., \& Warokka, A. (2011). Service quality and students' satisfaction at higher learning institutions: The competing dimensions of Malaysian universities' competitiveness. The Journal of Southeast Asian Research, 2011, 1-10.

8. Zancajo, A. (2018). Educational Providers in the Marketplace: Schools' Marketing Responses in Chile. International Journal of Educational Research, 88, 166-176.

9. Tahir, A. G., Rizvi, S. A. A., Khan, M. B., \& Ahmad, F. (2017). Keys of Educational Marketing. Journal of Applied Environmental and Biological Sciences, 7(1), 180-187.

10. Kopanakis, I., Vassakis, K., \& Mastorakis, G. (2016, June). Big Data in Data-Driven Innovation: Applications, prospects and limitations in Marketing. In 4 th International Conference on Contemporary Marketing Issues ICCMI June 2224, 2016 Heraklion, Greece (p. 701). [

11. Raynard, M. (2017). Understanding academic ebooks through the diffusion of innovations theory 
as a basis for developing effective marketing and educational strategies. The Journal of Academic Librarianship, 43(1), 82-86.

12. Nieves, J., \& Diaz-Meneses, G. (2016). Antecedents and outcomes of marketing innovation. International Journal of Contemporary Hospitality Management.

13. $\left.{ }^{1}\right]$ Burhanudin, J., Kartini, D., Sucherly, S., \& Komaladewi, R. (2019, April). Marketing Performance Through Competitive Advantage Based on Innovation in Educational Service at Private Polytechnics in Indonesia. In Journal of International Conference Proceedings, 2(1), 48.

14. Alma, B., \& Priansa, D. J. (2009). Manajemen bisnis syariah: penuntun perkuliahan bagi para mahasiswa, pencerahan bagi para pedagang, pengembangan marketing syariah/spiritual marketing bagi para pengusaha. Alfabeta.

15. Halbheer, D., Fruchter, G. E., Gerstner, E., \& Reutterer, T. (2019). Funding Mechanisms for Higher Education: A Marketing Perspective. Available at SSRN 3377734.

16. Mutohar, P. M., Jani, \& Trisnantari, H. E. (2020) Contribution of Visionary Leadership, Lecturer Performance, and Academic Culture to the Competitiveness of Islamic Higher Education in Indonesia. Journal of Advances in Education and Philosophy (JAEP), 4(2): 29-45

17. Olii, K. R. R., \& Nurcaya, I. N. (2016). Peran Kepuasan Pelanggan Dalam Memediasi Pengaruh Experiential Marketing Terhadap Pembelian Ulang Tiket Pesawat Pada PT Jasa Nusa Wisata Denpasar. E-Jurnal Manajemen, 5(8).

18. Muhammad, M., \& Artanti, Y. (2016). The impact of experiential marketing on word of mouth with customer satisfaction as a intervening variable. Jurnal Dinamika Manajemen, 7(2), 182190.

19. Abedi, H., \& Ghelich Khani, M. H. (2016). The Effect of Experiential Marketing, Destination Image and Corporate Image on Guests' Satisfaction in Hotels (Case Study: 4 and 5 star Tehran Parsian Hotels). Iranian Business Management, 8(1), 183-204.

20. Wiedmann, K. P., Labenz, F., Haase, J., \& Hennigs, N. (2018). The power of experiential marketing: exploring the causal relationships among multisensory marketing, brand experience, customer perceived value and brand strength. Journal of Brand Management, 25(2), 101-118.

21. Mukiira, E. M., Musau, M. C., \& Munyao, M. J. (2017). Effect of experiential marketing in building brand equity: A case of selected Unilever Tanzania brands. International Journal of Supply Chain Management, 2(1), 1-31.

22. Azeem, M. A., \& Hussain, S. (2018). Making Sense in Marketing: Sensory Strategies for International Quick Service
Restaurants. MANTHAN: Journal of Commerce and Management, 5(2), 37-52.

23. Muthiah, K., \& Suja, S. (2017). A Study on Sense, Feel, Think, Act, Relate Factors of Experiential Marketing in Retailing. Transformations in Business \& Economics, 16(1).

24. McClinchey, K. A. (2016). Going forward by looking back: memory, nostalgia and meaningmaking in marketing for a sense of place.

25. Katrine, D., \& Harini, C. (2018). The Analysis of Effect of Sense, Feel, Think, Act, and Relate as The Experiential Marketing Variables to Customer Loyality of Andelir Hotel Semarang. Journal of Management, 4(4).

26. Muthiah, K., \& Suja, S. (2017). A Study on Sense, Feel, Think, Act, Relate Factors of Experiential Marketing in Retailing. Transformations in Business \& Economics, 16(1).

27. Wahyuningtyas, F. M., Achmad, F., \& Zainul, A. (2017). The effect of experiential marketing on satisfaction and its impact on customer loyalty. Russian Journal of Agricultural and Socio-Economic Sciences, 61(1).

28. Ungerman, O., Dedkova, J., \& Gurinova, K. (2018). The impact of marketing innovation on the competitiveness of enterprises in the context of industry 4.0. Journal of Competitiveness, 10(2), 132.

29. Gupta, S., Malhotra, N. K., Czinkota, M., \& Foroudi, P. (2016). Marketing innovation: A consequence of competitiveness. Journal of Business Research, 69(12), 5671-5681.

30. Lin, M. T. Y. (2019). Effects of Experiential Marketing on Experience Value and Customer Satisfaction in Ecotourism. Ekoloji Dergisi, (107).

31. de Lima, A. P., Pacheco, J., \& Silva, P. (2020). Effects of Experience on Valuing a Tourist Event: A Theoretical Review and Propositions. In Advances in Tourism, Technology and Smart Systems (pp. 447-458). Springer, Singapore.

32. Handal, Nehemia S. (2010) Analisis Pengaruh Experiential Marketing Terhadap Loyalitas. Jurnal Manajemen Universitas Diponegoro.

33. Maghnati, F., Ling, K. C., \& Nasermoadeli, A. (2012). Exploring the relationship between experiential marketing and experiential value in the smartphone industry. International Business Research, 5(11), 169.

34. Nigam, A. ( 2012). Modeling Relationship between Experiential Marketing, Experiential Value and Purchase Intension in Organized Quick Service Chain Restaurants Using Structural Equation Modeling Approach, IJCSMS International Journal of Computer Science \& Management Studies, 12

35. Sallis, E. (2014). Total quality management in education. Routledge.

36. Alma, B., \& Hurriyati, R. (2008). Manajemen corporate \& strategi pemasaran jasa pendidikan. Alfabeta. 
37. Schmitt, B. H. (1999). Experiential marketing: How to get companies to sense, feel, think, act, and relate to your company and brands. New York: The Fress Press

38. Sugiyono. (2012). Metode Penelitian Pendidikan Pendekatan Kuantitatif, Kualitatif, dan $R \& D$, (Bandung: Alfabeta.

39. Ghozali, I. (2014) Konsep dan Aplikasi Dengan Program AMOS 22, Semarang: Badan Penerbit Universitas Diponegoro.

40. Singgih, S. (2015). AMOS 22 untuk Structural Equation Modelling, Jakarta: PT Elex Media Komputindo.

41. Ghozali, I. (2014). Konsep dan Aplikasi Dengan Program AMOS 22, Semarang: Badan Penerbit Universitas Diponegoro.

42. Singgih, S. (2015). AMOS 22 untuk Structural Equation Modelling, Jakarta: PT Elex Media Komputindo.

43. Solimun, M. S. (2002). Structural Equation Modelling (SEM) Lisrel dan Amos. Malang: Fakultas MIPA Universitas Brawijaya.

44. Wahyuningtyas, F. M., Achmad, F., \& Zainul, A. (2017). The effect of experiential marketing on satisfaction and its impact on customer loyalty. Russian Journal of Agricultural and Socio-Economic Sciences, 61(1).

45. Azeem, M. A., \& Hussain, S. (2018). Making Sense in Marketing: Sensory Strategies for International Quick Service Restaurants. MANTHAN: Journal of Commerce and Management, 5(2), 37-52.

46. Marginson, S. (2004). Competition and markets in higher education: A 'glonacal'analysis. Policy futures in Education, 2(2), 175-244.

47. Chen, Y. K., \& Hsieh, T. (2010). A study of the relationship among experiential marketing, experiential value and customer satisfaction. Journal of Statistics and Management Systems, 13(6), 1283-1303.

48. Lin, M. T. Y. (2019). Effects of Experiential Marketing on Experience Value and Customer Satisfaction in Ecotourism. Ekoloji Dergisi, (107).

49. Chen, Y. K., \& Hsieh, T. (2010). A study of the relationship among experiential marketing, experiential value and customer satisfaction. Journal of Statistics and Management Systems, 13(6), 1283-1303.

50. Katrine, D., \& Harini, C. (2018). The Analysis of Effect of Sense, Feel, Think, Act, and Relate as The Experiential Marketing Variables to Customer Loyality of Andelir Hotel Semarang. Journal of Management, 4(4).

51. Lee, S. M. (2018). The Influence of the Experiential Marketing Factors of Restaurant on the Brand Image, Satisfaction, and Customer Loyalty: Focused on Restaurants in Complex Shopping Mall. Culinary Science \& Hospitality Research, 24(2), 112-118.
52. Jeon, H. (2013). The effect of experiential marketing on customer satisfaction and revisit intention of beauty salon franchise stores. Journal of Fashion Business, 17(3), 109-121.

53. İşler, D. B. (2015). The Effect of Experiential Marketing on Satisfaction of Microblogging Sites: A Study on Twitter Users. International Journal of Social Ecology and Sustainable Development (IJSESD), 6(1), 28-43.

54. Wahyuningtyas, F. M., Achmad, F., \& Zainul, A. (2017). The effect of experiential marketing on satisfaction and its impact on customer loyalty. Russian Journal of Agricultural and Socio-Economic Sciences, 61(1).

55. Schmitt, B. H. (1999). Experiential marketing: How to get companies to sense, feel, think, act, and relate to your company and brands. New York: The Fress Press

56. Vogt, R. A., \& Kaiser, L. L. (2008). Still a time to act: A review of institutional marketing of regionally-grown food. Agriculture and Human Values, 25(2), 241-255.

57. Grundey, D. (2008). Experiential marketing vs. traditional marketing: Creating rational and emotional liaisons with consumers. The Romanian Economic Journal, 29(3), 133-151.

58. Litvinova, T., Morozova, I., \& Yatsechko, S. (2015). Experiential marketing as a tool of improvement of competitiveness of enterprises in the market of bread and bakery products. Mediterranean Journal of Social Sciences, 6(3 S6), 11-11.

59. Chen, Y. K., \& Hsieh, T. (2010). A study of the relationship among experiential marketing, experiential value and customer satisfaction. Journal of Statistics and Management Systems, 13(6), 1283-1303.

60. Jeon, H. (2013). The effect of experiential marketing on customer satisfaction and revisit intention of beauty salon franchise stores. Journal of Fashion Business, 17(3), 109-121.

61. Katrine, D., \& Harini, C. (2018). The Analysis of Effect of Sense, Feel, Think, Act, and Relate as The Experiential Marketing Variables to Customer Loyality of Andelir Hotel Semarang. Journal of Management, 4(4).

62. Lee, S. M. (2018). The Influence of the Experiential Marketing Factors of Restaurant on the Brand Image, Satisfaction, and Customer Loyalty: Focused on Restaurants in Complex Shopping Mall. Culinary Science \& Hospitality Research, 24(2), 112-118.

63. Mukiira, E. M., Musau, M. C., \& Munyao, M. J. (2017). Effect of experiential marketing in building brand equity: A case of selected Unilever Tanzania brands. International Journal of Supply Chain Management, 2(1), 1-31. 